\title{
Analisis penerapan sistem informasi akuntansi dan pengendalian internal terhadap kualitas laporan keuangan pada Koperasi Serba Usaha (KSU) Kencana Makmur Sugihan Tahun $2017-2020$
}

\author{
Kusuma Wijaya**, Saiful Ihsan Al Faruq ${ }^{2}$ \\ ${ }^{1}$ Politeknik Pusmanu Pekalongan \\ ${ }^{2}$ Universitas Islam Lamongan \\ *E-mail korespodensi: Kusumawijaya785@gmail.com
}

\begin{abstract}
One of the factors supporting the quality of financial reports is the accounting information system and internal control. This study aims to test the analysis of internal control and the application of accounting information systems to the quality of financial reports at the Kencana Makmur Sugihan 2017-2020 Multipurpose Cooperative (KSU). This research uses quantitative analysis methods. The population in this study were all employees of the KSU Kencana Makmur Sugihan, totaling 60 people, while the sample in this study were employees of accounting, administration (bookkeeper), and internal auditors as many as 40 respondents. The data collection method used questionnaires, the data analysis method used multiple linear regression analysis, and the data processing process used SPSS (Statistical Package for Social Science) version 20. The results showed that the analysis of internal control and the application of accounting information systems simultaneously affected the quality of financial reports. whereas partially the application of accounting information systems and internal controls has a significant effect on the quality of financial reports.
\end{abstract}

Keywords: Accounting information systems, Internal control, Quality of Financial Statements.

\begin{abstract}
Abstrak
Salah satu faktor pendukung kualitas laporan keuangan yaitu sistem informasi akuntansi dan pengendalian internal. Penelitian ini bertujuan untuk menguji analisis pengendalian internal dan penerapan sistem informasi akuntansi terhadap kualitas laporan keuangan pada Koperasi Serba Usaha (KSU) Kencana Makmur Sugihan Tahun 2017-2020. Penelitian ini menggunakan metode analisis kuantitatif. Populasi dalam penelitian ini adalah seluruh karyawan KSU Kencana Makmur Sugihan yang berjumlah 60 orang sedangkan sampel dalam penelitian ini adalah karyawan bagian akuntansi, administrasi (juru buku) dan internal auditor sebanyak 40 responden. Metode pengumpulan data menggunakan kuisioner, metode analisis data menggunakan analisis regresi linear berganda dan proses penngolahan data menggunakan SPSS (Statistical Package for Social Science) versi 20. Hasil penelitian menunjukkan bahwa analisis penerapan sistem informasi akuntansi dan pengendalian internal secara simultan berpengaruh terhadap kualitas laporan keuangan, sedangkan secara parsial penerapan sistem informasi akuntansi dan pengendalian internal berpengaruh signifikan terhadap kualitas laporan keuangan.
\end{abstract}

Kata kunci : Sistem informasi akuntansi, Pengendalian internal, Kualitas laporan keuangan 


\section{PENDAHULUAN}

Berdasarkan peraturan pemerintah Nomor 71 tahun 2010, laporan keuangan adalah laporan yang terstruktur mengenai posisi keuangan dan transaksi - transaksi yang dilakukan suatu entitas pelaporan. Kualitas laporan keuangan merupakan suatu hal yang sangat penting dalam perusahaan. Laporan keuangan menurut Ikatan Akuntansi Indonesia (IAI) merupakan bagian dari proses pelaporan keuangan. Laporan keuangan yang lengkap biasanya meliputi neraca, laporan laba rugi, laporan perubahan posisi keuangan. Menurut (Wijaya, 2018), Laporan keuangan bisa dikatakan berkualitas apabila memiliki karakteristik sebagai berikut : 1) relevan, dapat mempengaruhi pengguna dalam mengevaluasi peristiwa masa lalu atau masa kini dan memprediksi masa depan, serta mengoreksi hasil peristiwa masa lalu, 2) andal, bebas dari pengertian yang menyesatkan dan kesalahan material, 3) dapat dipahami, memakai istilah-istilah yang dapat dimengerti oleh pemakainya, 4) dapat dibandingkan dengan laporan keuangan sebelumnya atau laporan keuangan entitas pelaporan lain pada umumnya.

Sistem informasi akuntansi menurut Azhar (2018) merupakan kumpulan atau group dari sub sistem/bagian/komponen apapun baik fisik atau non fisik yang saling berhubungan satu sama lain dan bekerja sama secara harmonis untuk mengolah data transaksi yang berkaitan dengan masalah keuangan menjadi informasi keuangan. Sistem informasi akuntansi di rancang untuk menghasilkan informasi berupa informasi keuangan yang dibutuhkan oleh pihak eksternal maupun internal perusahaan.

Sistem pengendalian internal merupakan faktor pendukung ke 2 setelah sistem informasi akuntansi, dalam meningkatkan kualitas laporan keuangan. Sistem pengendalian internal merupakan suatu rencana organisasi dan metode terkoordinasi yang diterapkan dalam suatu perusahaan untuk melindungi aktiva, menjaga keakurasian dan keterpercayaan data akuntansi, meningkatkan efisiensi, dan meningkatkan kepatuhan terhadap kebijakan managemen, (Wijaya, 2018).

Koperasi memiliki berbagai jenis. Salah satunya adalah Koperasi Serba Usaha (KSU). KSU memiliki fungsi untuk meningkatkan produksi dan mensejahterakan masyarakat. KSU Kencana Makmur Sugihan yang dikenal dengan usaha simpan pinjam uang dan KSU merupakan koperasi yang bergerak di bidang usaha yang mana usaha yang dinaunginya berbagai macam usaha antara lain yaitu USP Konvensional, UJKS (Unit Jasa Keuangan Syari'ah), SAPRODI (Sarana produksi pertanian), Mini market, Agrobis, Unit peternakan, Unit produksi AMDK (Air Minum Dalam Kemasan dan lain-lain.

Dalam mendukung perencanaan perusahaan, membutuhkan informasi yang dapat memberikan gambaran mengenai kondisi perusahaan, terutama kondisi keuangan perusahaan. Laporan keuangan dapat menjadi sumber untuk mendapatkan informasi mengenai kondisi keuangan yang tepat dan akurat. Penggunaan karakteristik kualitatif laporan keuangan dalam analisis laporan keuangan diharapkan dapat membantu untuk mengetahui kondisi laporan keuangan perusahaan, terutama tingkat kualitas laporan keuangan perusahaan, dalam kurun waktu tertentu.

Berdasarkan latar belakang masalah yang telah dijelaskan, penulis merasa tertarik untuk melakukan penelitian lebih lanjut mengenai hal tersebut dan menuangkannya ke dalam skripsi dengan judul "Analisis Penerapan sistem informasi akuntansi dan pengendalian internal terhadap kualitas laporan keuangan pada koperasi serba usaha (KSU) Kencana Makmur Sugihan Tahun 2017-2020”

\section{METODE}

Variabel terikat (dependent variable) dalam penelitian ini adalah kualitas laporan keuangan. Sedangkan variabel bebas (independent variable) dalam penelitian ini adalah sistem informasi akuntansi dan pengendalian internal. 
Berdasarkan variabel yang diteliti, maka jenis penelitian yang digunakan dalam penelitian ini adalah penelitian yang bersifat kuantitatif yaitu penelitian yang menggunakan data angka dalam penyajian laporan data dan analisis yang menggunakan uji statistik (Sugiyono, 2013).

Populasi dalam penelitian ini adalah karyawan di KSU Kencana Makmur Sugihan, Solokuro, Lamongan yang berjumlah 60 karyawan sedangkan Sampel dalam penelitian ini adalah karyawan bagian pengendalian internal, sistem informasi akuntansi, dan laporan keuangan tahun 2017-2020 pada KSU Kencana Makmur Sugihan, Solokuro, Lamongan.

\section{Analisis data}

Analisis data merupakan kegiatan setelah data dari seluruh responden terkumpul. Kegiatan dalam analisis data adalah mengelompokkan data berdasarkan variabel dan jenis responden, menstabulasi data berdasarkan variabel dari seluruh responden, menyajikan data dari setiap variabel yang diteliti, melakukan perhitungan untuk menjawab rumusan masalah dan melakukan perhitungan untuk menguji hipotesis yang telah diajukan.

Teknik analisis data penelitian ini mengunakan analisis kuantitatif menggunakan alat bantu Software IBM SPSS Statistics Version 20. Kualitas data yang dihasilkan dari penggunaan instrumen penelitian dapat dievaluasi melalui 2 uji, yaitu : uji validitas dan uji reabilitas.

Uji kualitas data adalah dengan melakukan uji asumsi klasik untuk mengetahui kemungkinan terjadinya penyimpangan asumsi klasik. Dalam penelitian ini uji asumsi klasik yang digunakan adalah uji normalitas, uji autokolerasi, uji multikolinearitas, dan uji heteroskedastisitas.

Penelitian ini, menggunakan analisis regresi berganda untuk mengetahui pengaruh Sistem Informasi Akuntansi dan Pengendalian Internal terhadap Kualitas Laporan Keuangan pada Koperasi Serba Usaha (KSU) Kencana Makmur Sugihan. Analisis regresi merupakan analisis yang digunakan untuk memprediksi seberapa jauh perubahan nilai variabel dependen bila nilai variabel independen dimanipulasi/ diubah-ubah atau dinaikturunkan.

Peneliti menggunakan analisis regresi berganda karena dalam penelitian ini X1= Sistem Informasi Akuntansi berpengaruh positif terhadap Kualitas Laporan Keuangan, $\mathrm{X} 2$ = Pengendalian Internal berpengaruh positif terhadap Kualitas Laporan Keuangan. Serta Y = Kualitas Laporan Keuangan.

Pembuktian terhadap hipotesis pada penelitian ini menggunakan model regresi berganda sebagai berikut :

$\mathbf{Y}=\boldsymbol{\alpha}+\mathbf{b}_{1} \mathbf{X}_{1}+\mathbf{b}_{2} \mathbf{X}_{2}+\mathbf{e}$.

Keterangan :

$\mathrm{Y}=$ Variabel terikat (kualitas laporan keuangan)

$\mathrm{X}_{1} \quad=$ Variabel bebas (penerapan sistem informasi akuntansi)

$\mathrm{X}_{2}=$ Variabel bebas (pengendalian internal)

A $\quad=$ Konstanta

$\mathrm{e} \quad=$ Variabel pengganggu/residual

$b_{1}, b_{2}=$ Koefisien regresi

\section{HASIL DAN PEMBAHASAN}

Penelitian ini dilakukan dengan cara menyebarkan kuisoner sejumlah 40 ke karyawan bagian acounting, administrasi (juru buku) dan internal auditor di Koperasi Serba Usaha (KSU) Kencana Makmur Sugihan, sebagai berikut: 
Tabel 1. Distribusi penyebaran kuisioner

\begin{tabular}{llcc} 
No & Keterangan & $\begin{array}{c}\text { Kuisioner yang } \\
\text { disebar }\end{array}$ & $\begin{array}{c}\text { Kuisioner yang } \\
\text { kembali }\end{array}$ \\
\hline 1 & $\begin{array}{l}\text { KSU Kencana } \\
\text { Makmur }\end{array}$ & 40 & 40 \\
\hline Total & & $\mathbf{4 0}$ & $\mathbf{4 0}$ \\
\hline
\end{tabular}

Sumber : Data diolah, 2020

Berdasarkan Tabel 1 dapat dijelaskan bahwa dari 40 kuesioner yang berhasil didistribusikan, 40 kuesioner yang kembali atau 40\%, 0 kuesioner yang tidak kembali atau $0 \%$, dan 40 kuesioner yang dapat diolah atau $40 \%$.

Tabel 2. Karakteristik responden dilihat dari umur

\begin{tabular}{llcr}
\hline Karakteristik Responden & Jumlah (orang) & Persentase \\
\hline \multirow{4}{*}{ Usia } & 18-25 Tahun & 2 & $5 \%$ \\
& 26-33 Tahun & 7 & $18 \%$ \\
& 34-41 Tahun & 25 & $63 \%$ \\
& 42 Tahun Keatas & 6 & $15 \%$ \\
\cline { 2 - 4 } & Jumlah & 40 & $100 \%$ \\
\hline
\end{tabular}

Sumber : Data diolah, 2020

Berdasarkan Tabel 2 dapat dijelaskan bahwa dari 40 responden terdapat 2 responden yang berumur 18-25 tahun atau 5\%, 7 responden yang berumur antara 26-33 tahun atau $18 \%, 25$ responden yang berumur antara 34-41 tahun atau $63 \%$, dan untuk responden yang berumur diatas 42 tahun terdapat 6 responden atau $15 \%$.

Tabel 3. Karakteristik responden dilihat dari jenis kelamin

\begin{tabular}{clcr}
\hline \multicolumn{2}{c}{ Karakteristik Responden } & $\begin{array}{l}\text { Jumlah } \\
\text { (orang) }\end{array}$ & \multicolumn{2}{c}{ Persentase } \\
\hline \multirow{3}{*}{ Jenis kelamin } & Laki-laki & 22 & $55 \%$ \\
& Perempuan & 18 & $45 \%$ \\
\cline { 2 - 4 } & Jumlah & 40 & $100 \%$ \\
\hline
\end{tabular}

Sumber : Data diolah, 2020

Berdasarkan tabel diatas dapat dijelaskan bahwa dari 40 responden terdiri dari 22 responden laki-laki atau 55\% dan 18 responden perempuan atau $45 \%$.

Tabel 4. Karakteristik responden dilihat dari lama bekerja

\begin{tabular}{llcr}
\hline \multicolumn{2}{c}{ Karakteristik responden } & $\begin{array}{c}\text { Jumlah } \\
\text { (orang) }\end{array}$ & \multicolumn{2}{c}{ Persentase } \\
\hline \multirow{3}{*}{ Lama bekerja } & 20-30 Tahun & 10 & $25 \%$ \\
& 30 Tahun ke atas & 30 & $75 \%$ \\
\cline { 2 - 4 } & Jumlah & 40 & $100 \%$ \\
\hline
\end{tabular}

Sumber : Data diolah, 2020

Dari Tabel 4 dapat dijelaskan bahwa 40 responden yang bekerja selama 20-30 tahun terdapat 10 responden atau $25 \%$ dan yang bekerja 30 tahun ke atas terdapat 30 responden atau $75 \%$. 
Tabel 5. Karakteristik responden dilihat dari latar belakang pendidikan

\begin{tabular}{llcr}
\hline \multicolumn{1}{c}{ Karakteristik responden } & $\begin{array}{c}\text { Jumlah } \\
\text { (orang) }\end{array}$ & \multicolumn{1}{c}{ Persentase } \\
\hline \multirow{5}{*}{ Pendidikan } & SMA & 0 & $0 \%$ \\
& Diploma (D3) & 0 & $0 \%$ \\
& Sarjana (S1) & 40 & $100 \%$ \\
& Pascasarjana (S2) & 0 & $0 \%$ \\
& S3 & 0 & $0 \%$ \\
\cline { 2 - 3 } & Jumlah & 40 & $100 \%$ \\
\hline
\end{tabular}

Sumber : Data diolah, 2020

Dari tabel 5 dapat dijelaskan bahwa responden yang berlatar belakang pendidikan SMA, Diploma (D3), Pascasarjana (S2), S3 terdapat 0 responden atau 0\%, sedangkan latar belakang pendidikan pendidikan Sarjana (S1) terdapat 40 responden atau $100 \%$.

Tabel 6. Karakteristik responden dilihat dari latar belakang bagian atau jabatan

\begin{tabular}{llcr}
\hline \multicolumn{1}{c}{ Karakteristik Responden } & $\begin{array}{c}\text { Jumlah } \\
\text { (orang) }\end{array}$ & Persentase \\
\hline \multirow{3}{*}{ Bagian/Jabatan } & Akunting & 19 & $48 \%$ \\
& Administrasi (juru buku) & 19 & $48 \%$ \\
& Internal Auditor & 2 & $5 \%$ \\
\cline { 2 - 4 } & Jumlah & 40 & $100 \%$ \\
\hline
\end{tabular}

Sumber : Data diolah, 2020

Dari Tabel 6 dapat dijelaskan bahwa responden yang berlatar belakang jabatan akunting dan administrasi (juru buku) terdapat 19 responden atau 48\%, sedangkan jabatan internal auditor terdapat 2 responden atau $5 \%$.

\section{Hasil uji data}

Uji validitas digunakan untuk mengukur pertanyaan pada kuesioner mampu untuk mengungkapkan sesuatu yang akan diukur oleh suatu kuesioner. Uji signifikansi dilakukan dengan membandingkan nilai $r_{\text {hitung dengan }} r_{\text {tabel }}$ pengujian validitas menggunakan product moment dengan melihat nilai signifikan $=5 \%(0,05)$.

Tabel 7. Hasil uji reabilitas

\begin{tabular}{clccc}
\hline No & \multicolumn{1}{c}{ Variabel } & $\begin{array}{c}\text { Koefisien } \\
\text { Alfa }\end{array}$ & $\begin{array}{c}\text { Standart } \\
\text { Reliabilitas }\end{array}$ & Keterangan \\
\hline 1 & Sistem Informasi Akuntansi (X1) & 0,765 & 0,6 & Reliabel \\
2 & Pengendalian Internal (X2) & 0,752 & 0,6 & Reliabel \\
3 & Kualitas Laporan Keuangan (Y) & 0,937 & 0,6 & Reliabel \\
\hline
\end{tabular}

Sumber : Data diolah, 2020

Hasil pengujian reliabilitas dengan SPSS metode Alpha Cronbach's menunjukkan nilai alpha pada semua variabel bebas yaitu Sistem Informasi Akuntansi (X1), Pengendalian Internal dan variabel terikat yaitu Kualitas Laporan Keuangan lebih besar dari standar reliabilitas $(0,6)$ dengan tingkat signifikan $\alpha=5 \%$ dan $n=40$ ternyata diperoleh koefisien Alpha masing-masing variabel adalah > 0,6 yang artinya instrumen yang digunakan reliabel. 
Tabel 8. Hasil analisis statistik deskriptif

\begin{tabular}{lrrrrr}
\hline & \multicolumn{5}{c}{ Descriptive Statistics } \\
& Ninimum & Maximum & Mean & Std. Deviation \\
\hline Total_x1 & 40 & 30 & 49 & 40,45 & 4,935 \\
Total_x2 & 40 & 30 & 48 & 39,45 & 4,619 \\
Total_y & 40 & 31 & 50 & 43,63 & 5,197 \\
Valid N (listwise) & 40 & & & & \\
\hline
\end{tabular}

Sumber : Data diolah, 2020

Tabel diatas menunjukkan hasil pengukuran statistik deskriptif terhadap variabel dari 40 responden. Dari tabel diatas dapat dilihat Sistem Informasi Akuntansi $\left(\mathrm{X}_{1}\right)$ memiliki mean atau rata-rata sebesar 40,454, dengan nilai standar devisiasi sebesar 4,935 dan nilai minimum sebesar 30 serta nilai maximum sebesar 49. Pengendalian Internal $\left(\mathrm{X}_{2}\right)$ memiliki mean atau rata-rata sebesar 39,45 dengan nilai standar devisiasi sebesar 4,619 dan nilai minimum sebesar 30 serta nilai maximum sebesar 48 dan Kualitas Laporan Keuangan (Y) memiliki mean atau rata-rata sebesar 43,63 dengan nilai standar devisiasi sebesar 5,197 dan nilai minimum sebesar 31 serta nilai maximum sebesar 50 .

Tabel 9. Hasil uji normalitas

One-Sample Kolmogorov-Smirnov Test

\begin{tabular}{|c|c|c|}
\hline & & $\begin{array}{l}\text { Unstandardized } \\
\text { Residual }\end{array}$ \\
\hline $\mathrm{N}$ & & 40 \\
\hline \multirow{3}{*}{ Normal Parameters ${ }^{\mathrm{a}, \mathrm{b}}$} & Mean & $0 \mathrm{E}-7$ \\
\hline & Std. Deviation & 1,42837429 \\
\hline & Absolute &, 091 \\
\hline \multirow{2}{*}{ Most Extreme Differences } & Positive & 079 \\
\hline & Negative &,- 091 \\
\hline Kolmogorov-Smirnov Z & &, 575 \\
\hline Asymp. Sig. (2-tailed) & & ,896 \\
\hline
\end{tabular}

Sumber : Data diolah, 2020

Berdasarkan tabel diatas dapat dilihat bahwa nilai Kolmogorov-Smirnov memiliki nilai sebesar 0,573 dan Asymp. Sig. sebesar 0,896 lebih besar dari 0,05, sehingga dapat disimpulkan bahwa data yang digunakan berdistribusi normal.

Scatterplot

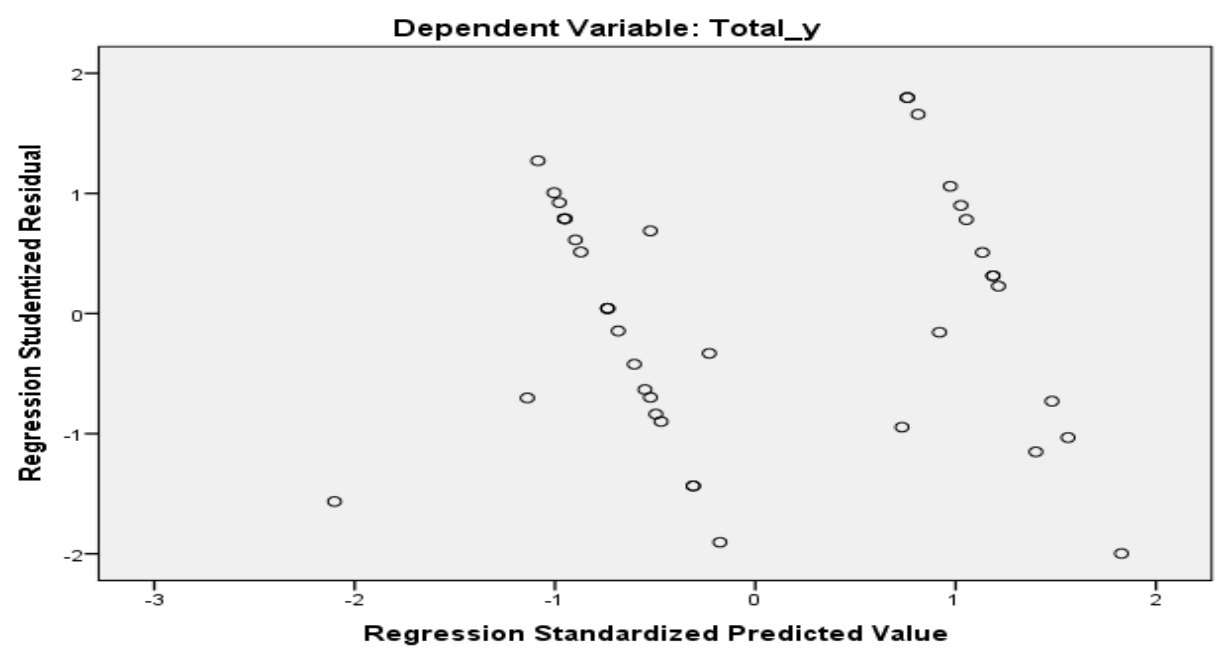

Gambar 1. Hasil uji heterokedastisitas 
Dari gambar diatas terlihat bahwa sebaran titik tidak membentuk suatu pola/alur tertentu, sehingga dapat disimpulkan tidak terjadi heteroskedastisitas. Asumsi klasik dalam model ini terpenuhi, yaitu terbebas dari heteroskedastisitas.

Berdasarkan Uji Multikolinearitas, diperoleh nilai toleransi untuk sistem informasi (X1) dan pengendalian internal (X2) terhadap kualitas laporan keuangan adalah 0,103> 0,10 dan nilai VIF sebesar 9,705 < 10,00 sehingga dapat disimpulkan bahwa tidak terjadi multikolinearitas pada variabel sistem informasi akuntansi dan pengendalian internal terhadap kualitas laporan keuangan.

Tabel 10. Hasil uji multikolinearitas

\begin{tabular}{|c|c|c|c|c|c|c|c|c|}
\hline \multicolumn{9}{|c|}{ Coefficients $^{\mathrm{a}}$} \\
\hline & \multirow{2}{*}{ Model } & \multicolumn{2}{|c|}{$\begin{array}{l}\text { Unstandardized } \\
\text { Coefficients }\end{array}$} & \multirow{2}{*}{$\begin{array}{c}\begin{array}{c}\text { Standardized } \\
\text { Coefficients }\end{array} \\
\text { Beta }\end{array}$} & \multirow{2}{*}{$\mathbf{t}$} & \multirow{2}{*}{ Sig. } & \multicolumn{2}{|c|}{ Collinearity Statistics } \\
\hline & & B & Std. Error & & & & Tolerance & VIF \\
\hline & (Constant) & 1,078 & 2,021 & &, 534 & ,597 & & \\
\hline 1 & Total_x1 & ,401 & , 148 &, 381 & 2,707 &, 010 &, 103 & 9,705 \\
\hline & Total_x2 & ,667 & , 158 &, 593 & 4,212 & 000 & , 103 & 9,705 \\
\hline
\end{tabular}

a. Dependent Variable: Total_y

Sumber : Data diolah, 2020

Berdasarkan Uji Autokorelasi dengan metode Runt Test diperoleh nilai Asymp. Sig. sebesar 2.068 lebih besar dari 0,05, sehingga dapat disimpulkan bahwa tidak terjadi autokorelasi pada sistem informasi akuntansi dan pengendalian internal terhadap kualitas laporan keuangan.

Tabel 11. Hasil uji autokorelasi

\begin{tabular}{|c|c|c|c|c|c|}
\hline \multicolumn{6}{|c|}{ Model Summaryb } \\
\hline Model & $\mathbf{R}$ & R Square & $\begin{array}{l}\text { Adjusted R } \\
\text { Square }\end{array}$ & $\begin{array}{c}\text { Std. Error of the } \\
\text { Estimate }\end{array}$ & Durbin-Watson \\
\hline 1 &, $961^{\mathrm{a}}$ & ,924 & 920 & 1,466 & 2, \\
\hline
\end{tabular}

a. Predictors: (Constant), Total_x2, Total_x1

b. Dependent Variable: Total_y

Sumber : Data diolah, 2020

Berdasarkan nilai konstanta dan koefisien regresi pada Tabel 12 diatas, diketahui persamaan regresinya sebagai berikut:

$\mathbf{Y}=\alpha+\mathbf{b}_{1} \mathbf{X}_{1}+\mathbf{b}_{2} \mathbf{X}_{2}$

$Y=1,078+0,401 X_{1}+0,667 X_{2}$

Tabel 12. Hasil uji regresi linear berganda

\begin{tabular}{|c|c|c|c|c|c|c|}
\hline \multicolumn{7}{|c|}{ Coefficients $^{\mathrm{a}}$} \\
\hline & \multirow{2}{*}{ Model } & \multicolumn{2}{|c|}{ Unstandardized Coefficients } & \multirow{2}{*}{$\begin{array}{c}\begin{array}{c}\text { Standardized } \\
\text { Coefficients }\end{array} \\
\text { Beta }\end{array}$} & \multirow[t]{2}{*}{$\mathbf{t}$} & \multirow[t]{2}{*}{ Sig. } \\
\hline & & $\mathrm{B}$ & Std. Error & & & \\
\hline \multirow{3}{*}{1} & (Constant) & 1,078 & 2,021 & & ,534 & ,597 \\
\hline & Total_x1 & ,401 &, 148 & ,381 & 2,707 & 010 \\
\hline & Total_x2 & ,667 &, 158 & ,593 & 4,212 &, 000 \\
\hline
\end{tabular}

a. Dependent Variable: Total_y

Sumber : Data diolah, 2020 
Dari persamaan nilai regresi linear berganda diatas, maka dapat dijelaskan: 1).Nilai konstanta $(\alpha)$ sebesar 1,078 artinya variabel kualitas laporan keuangan bernilai positif sebesar 1,078. 2) Nilai koefisien regresi variabel penerapan sistem informasi akuntansi (b) bernilai positif sebesar 0,401, artinya setiap kenaikan satu satuan variabel sistem informasi akuntansi, akan meningkatkan kualitas lapoaran keuangan sebesar 0,401 dengan asumsi variabel bebas yang lain bernilai tetap, 3) Nilai koefisien regresi variabel pengendalian internal $\left(b_{2}\right)$ bernilai positif sebesar 0,667 , artinya setiap kenaikan satu satuan variabel pengendalian internal, akan meningkatkan kualitas laporan keuangan sebesar 0,667 dengan asumsi variabel bebas yang lain bernilai tetap.

\section{Hasil hipotesis}

Dalam penelitian ini uji t digunakan untuk menguji koefesien regresi secara parsial dari masing-masing variabel independen dengan variabel dependen yaitu pengaruh penerapan Sistem Informasi Akuntansi dan Pengendalian Internal terhadap Kualitas Laporan Keuangan. Berikut ini merupakan hasil dari uji Hipotesis secara parsial (Uji t). Uji statistik $\mathrm{t}$ pada dasarnya menunjukkan seberapa jauh pengaruh satu variabel penjelas/independen secara individual menerangkan variabel dependen (Ghozali , 2010).

Tabel 13. Hasil uji hipotesis secara parsial (uji t)

\section{Coefficients $^{\mathrm{a}}$}

\begin{tabular}{|c|c|c|c|c|c|c|}
\hline & \multirow{2}{*}{ Model } & \multicolumn{2}{|c|}{$\begin{array}{l}\text { Unstandardized } \\
\text { Coefficients }\end{array}$} & \multirow{2}{*}{$\begin{array}{c}\text { Standardized } \\
\text { Coefficients } \\
\text { Beta }\end{array}$} & \multirow[t]{2}{*}{$\mathbf{t}$} & \multirow{2}{*}{ Sig. } \\
\hline & & B & Std. Error & & & \\
\hline \multirow{3}{*}{1} & (Constant) & 1,078 & 2,021 & & ,534 & ,597 \\
\hline & Total_x1 & ,401 &, 148 & ,381 & 2,707 & ,010 \\
\hline & Total_x2 & ,667 & , 158 & ,593 & 4,212 & , 000 \\
\hline
\end{tabular}

a. Dependent Variable: Total_y

Sumber : Data diolah, 2020

Dari hasil uji output SPSS coefficient yang dirangkum dalam tabel 3.1, maka dapat disimpulkan hasil pengujian pengaruh secara parsial variabel independen yang terdiri dari Sistem Informasi Akuntansi dan Pengendalian Internal terhadap Kualitas Laporan Keuagan pada KSU kencana makmur Sugihan tahun 2017-2020 adalah sebagai berikut:

\section{Hipotesis (H1)}

Berdasarkan hasil pengelolahan data yang ditunjukkan pada tabel diatas menunjukkan bahwa variabel Sistem Informasi Akuntansi diperoleh nilai yang signifikan sebesar 0,010 yang berada lebih kecil dari nilai signifikan umumnya 0,05 dan dapat di simpulkan bahwa variabel Sistem Informasi Akuntansi berpengaruh terhadap Kualitas Laporan Keuangan, maka dari itu hipotesis pertama H1 diterima.

\section{Hipotesis (H2)}

Berdasarkan hasil uji pengelolahan data diatas hipotesis kedua yaitu menguji Pengendalian Internal terhadap Kualitas Laporan Keuangan. Nilai signifikan sebesar 0,000 yang berada lebih kecil dari nilai signifikan 0,05 sehingga variabel Pengendalian Internal berpengaruh terhadap Kualitas Laporan Keuangan, maka dari itu hipotesis yang 
ke dua $\mathrm{H} 2$ diterima. Uji F digunakan untuk menguji apakah ada pengaruh yang signifikan atau tidak antara variabel bebas Sistem Informasi Akuntansi dan Pengendalian Internal secara bersama-sama (simultan) terhadap variabel terikat yaitu Kualitas Laporan Keuangan.

Tabel 14. Hasil uji hipotesis secara simultan (Uji F)

\begin{tabular}{llrrrrr}
\multicolumn{7}{c}{ ANOVA $^{\text {a }}$} \\
\hline Model & & Sum of Squares & Df & Mean Square & \multicolumn{1}{c}{ F } & \multicolumn{1}{c}{ Sig. } \\
\hline \multirow{3}{*}{1} & Regression & 973,805 & 2 & 486,903 & 226,410 &, $000^{\mathrm{b}}$ \\
& Residual & 79,570 & 37 & 2,151 & & \\
& Total & 1053,375 & 39 & & & \\
\hline
\end{tabular}

a. Dependent Variable: Total_y

b. Predictors: (Constant), Total_x2, Total_x1

Sumber : Data diolah, 2020

Dari hasil perhitungan dengan menggunakan program SPSS 20 dapat diketahui bahwa pada angka $F$ hitung sebesar 226,410 dan nilai signifikansi sebesar $0,000<$ dari taraf signifikansi 0,05. Dengan demikian dapat disimpulkan bahwa secara simultan variabel bebas Sistem Informasi Akuntansi dan Pengendalian Internnal berpengaruh secara bersama-sama terhadap Kualitas Laporan Keuangan pada KSU kencana makmur Sugihan tahun 2017-2020, maka hipotesis ke 3 (H3) diterima.

Tabel 15. Hasil uji koefisien determinan $\left(\mathrm{R}^{2}\right)$

\begin{tabular}{rrrrrr}
\hline \multicolumn{6}{c}{ Model Summary $^{\mathbf{b}}$} \\
\hline Model & R & R Square & Adjusted R Square & $\begin{array}{c}\text { Std. Error of the } \\
\text { Estimate }\end{array}$ \\
\hline 1 &, $961^{\mathrm{a}}$ &, 924 &, 920 & 1,466 \\
\hline
\end{tabular}

a. Predictors: (Constant), Total_x2, Total_x1

b. Dependent Variable: Total_y

Sumber : Data diolah, 2020

Berdasarkan Tabel 15 diperoleh nilai koefisien determinan yang ditunjukkan dari nilai Adjusted R Squere yang ditunjujkan dari nilai Adjusted R Squere sebesar 0,920. hal ini berarti 0,920 persen menunjukkan bahwa variabel Kualitas Laporan Keuangan dapat dijelaskan oleh variabel independen yaitu Sistem Informasi Akuntansi dan Pengendalian Inetrnal.

\section{Pengaruh sistem informasi akuntansi terhadap kualitas laporan keuangan $\left(\mathrm{X}_{1}\right)$}

Berdasarkan hasil penelitian yang dilihat dari hasil uji regresi linear berganda menunjukkan bahwa nilai konstanta sebesar 1,078 artinya jika per variabel nilainya adalah 0, maka kualitas laporan keuangan (Y) nilainya 1,078. Nilai koefisien regresi variabel Sistem Informasi Akuntansi $\left(\mathrm{X}_{1}\right)$ bernilai positif 0,401 menunjukkan bahwa ada hubungan positif terhadap variabel Kualitas Laporan Keuangan (Y), dalam artian penerapan sistem informasi akuntansi mempunyai pengaruh yang positif terhadap kualitas laporan keuangan pada KSU Kencana Makmur Sugihan.

Hasil hipotesis uji t untuk variabel Penerapan Sistem Informasi Akuntansi $\left(\mathrm{X}_{1}\right)$ menunjukkan bahwa nilai t-hitung bernilai positif menunjukkan bahwa $\left(\mathrm{X}_{1}\right)$ mempunyai hubungan searah dengan (Y), nilai t-hitung sebesar 2,707, sedangkan t-tabel sebesar 1,687, maka dapat disimpulkan bahwa nilai t-hitung lebih besar dari t-tabel $(2,707>$ 1,687) dan dengan nilai signifikansi lebih kecil dari $0,05(0,010<0,05)$, maka dari hasil uji t ini dapat disimpulkan bahwa variabel penerapan Sistem Informasi Akuntansi $\left(\mathrm{X}_{1}\right)$ berpengaruh signifikan terhadap Kualitas Laporan Keuangan (Y), sehingga hipotesis pertama $\left(\mathrm{H}_{1}\right)$ menjelaskan bahwa penerapan Sistem Informasi Akuntansi berpengaruh 
signifikan terhadap Kualitas Laporan Keuangan pada KSU Kencana Makmur Sugihan, hipotesis $\left(\mathrm{H}_{1}\right)$ diterima.

\section{Pengaruh pengendalian internal terhadap kualitas keuangan $\left(\mathbf{X}_{2}\right)$}

Berdasarkan hasil penelitian yang dilihat dari hasil uji regresi linear berganda menunjukkan bahwa konstanta sebesar 1,078 artinya jika per variabel nilainya adalah 0 , maka Kualitas Laporan Keuangan (Y) nilainya 1,078. Nilai koefisien regresi variabel Pengendalian Internal $\left(\mathrm{X}_{2}\right)$ bernilai positif 0,667 menunjukkan bahwa ada hubungan positif terhadap variabel Kualitas Laporan Keuangan (Y).

Hasil uji t untuk variabel Pengendalian Internal $\left(\mathrm{X}_{2}\right)$ menunjukkan bahwa nilai thitung bernilai positif menunjukkan bahwa $\left(\mathrm{X}_{2}\right)$ mempunyai hubungan searah dengan (Y), nilai t-hitung sebesar 4,212 sedangkan t-tabel sebesar 1,687, maka dapat disimpulkan bahwa nilai t-hitung lebih besar dari t-tabel $(4,212>1,687)$ dan dengan nilai signifikansi lebih kecil dari $0,05(0,000<0,05)$, maka dari hasil uji t ini dapat disimpulkan bahwa variabel penerapan Pengendalian Internal $\left(\mathrm{X}_{2}\right)$ berpengaruh signifikan terhadap Kualitas Laporan Keuangan (Y). Sehingga hipotesis kedua $\left(\mathrm{H}_{2}\right)$ menyatakan Pengendalian Internal berpengaruh signifikan terhadap Kualitas Laporan Keuangan, maka hipotesis $\left(\mathrm{H}_{2}\right)$ diterima.

\section{Pengaruh secara simultan terhadap kualitas laporan keuangan}

Berdasarkan hasil penelitian yang dilihat dari hasil uji $\mathrm{F}$ untuk pengaruh secara simultan menunjukkan bahwa nilai F-hitung adalah 226,410 sedangkan nilai F-tabel adalah 4,11, maka dapat disimpulkan bahwa nilai F-hitung lebih besar dari nilai F-tabel $(226,410>4,11)$ dan dengan nilai signifikansi sebesar $(0,000<0,05)$, maka hasil uji $\mathrm{F}$ ini dapat disimpulkan bahwa variabel penerapan sistem informasi akuntansi dan pengendalian internal berpengaruh secara simultan terhadap kualitas laporan keuangan. Sehingga hipotesis $\left(\mathrm{H}_{3}\right)$ yang berbunyi secara simultan penerapan sistem informasi akuntansi dan pengendalian internal berpengaruh terhadap kualitas laporan keuangan, hipotesis $\left(\mathrm{H}_{3}\right)$ diterima. Hal ini membuktikan bahwa semakin baik kerja sistem informasi akuntansi dan pengendalian internal maka semakin baik pula kualitas laporan keuangan.

\section{KESIMPULAN DAN SARAN}

\section{Kesimpulan}

Berdasarkan hasil penelitian yang telah dilakukan membuktikan bahwa secara parsial penerapan sistem informasi akuntansi berpengaruh positif signifikan terhadap kualitas laporan keuangan yang dapat dilihat melalui nilai t-hitung $>$ dari nilai t-tabel $(2,707>$ $1,687)$ dan dengan nilai signifikan $<$ dari $0,05(0,010<0,05)$. Hasil penelitian ini berarti sistem informasi akuntansi yang dimiliki KSU Kencana Makmur Sugihan sudah diterapkan dengan baik dan efisien.

Berdsarkan hasil penelitian yang telah dilakukan membuktikan bahwa secara parsial pengendalian internal berpengaruh positif signifikan terhadap kualitas laporan keuangan yang dapat dilihat melalui nilai t-hitung $>$ dari nilai t-tabel $(4,212>1,687)$ dan dengan nilai signifikan $<$ dari $0,05(0,000<0,05)$. Hasil penelitian ini berarti pengendalian internal yang dimiliki KSU Kencana Makmur Sugihan sudah diterapkan dengan baik.

Berdasarkan hasil penelitian yang telah dilakukan membuktikan bahwa secara simultan penerapan sistem informasi akuntansi dan pengendalian internal berpengaruh simultan terhadap kualitas laporan keuangan yang dapat dilihat melalui nilai f-hitung $>$ dari nilai f-tabel $(226,410>4,11)$ dan dengan nilai signifikan $<$ dari $0,05(0,000<0,05)$. Hasil penelitian ini berarti penerapan sistem informasi akuntansi dan pengendalian 
internal yang dimiliki KSU Kencana Makmur Sugihan secara bersama-sama berpengaruh terhadap kualitas laporan keuangan.

\section{Keterbatasan}

Adapun keterbatasan dalam penelitian ini adalah: 1) Penelitian ini jumlah sampel yang dapat diteliti relatif kecil yaitu hanya sebanyak 40 responden dan hanya menggunakan 1 perusahaan, 2) Penelitian ini hanya berfokus pada karyawan di KSU Kencana Makmur, jadi penelitian ini hanya memiliki ruang lingkup yang terbatas, dan sulitnya bertemu dengan manager perusahaan terkait kesibukan, kepadatan dan keterbatasan waktu, 3) Penelitian ini hanya menggunakan 2 variabel yang mempengaruhi kualitas laporan keuangan, sedangkan masih banyak variabel lain yang mempengaruhi kualitas laporan keuangan.

\section{Saran}

Bagi perusahaan hasil penelitian ini diharapkan kepada KSU Kencana Makmur Sugihan untuk terus meningkatkan kualitas laporan keuangan perusahaan dengan cara memperhatikan kinerja sistem informasi akuntansi agar dapat memperoleh informasi yang relevan untuk dijadikan dasar dalam pengambilan keputusan, dan terus memperhatikan kinerja pengendalian internal agar laporan keuangan, aset perusahan tetap terjaga keamanannya.

Variabel yang digunakan penelitian ini sangat sedikit, yaitu hanya 2 variabel, oleh sebab itu pada penelitian selanjutnya dapat menambah variabel lain yang berhubungan dengan kualitas laporan keuangan seperti variabel kompetensi sumber daya manusia, dll. Sehingga dapat memberikan gambaran yang lebih luas mengenai apa saja yang dapat mempengaruhi kualitas laporan keuangan selain sistem informasi akuntansi dan pengendalian internal.

Jumlah populasi yang digunakan dalam penelitian ini hanya satu perusahaan, penelitian selanjutnya diharapkan dapat memperbanyak jumlah sampel yang akan digunakan, sehingga akan mendekati gambaran hasil yang lebih mendekati kondisi yang sebenarnya, dan diharapkan untuk menggunakan jenis perusahaan lain sebagai objek penelitian.

\section{DAFTAR PUSTAKA}

COSO. (2013). Pengaruh sistem informasi akuntansi dan pengendalian intern terhadap kualitas laporan keuangan daerah (survey pada dinas Kota Bandar Lampung dan Kota Metro). Skripsi. Program Studi Akuntansi. Fakultas Ekonomi Universitas Lampung: Bandar Lampung

Ghozali. (2013). Aplikasi analisis multivariate dengan program IBM SPSS 20. Badan Penerbit Universitas Diponegoro: Semarang.

Ikatan Akuntansi Indonesia. (2015). Standar akuntansi keuangan. Salemba Empat, Jakarta.

Munawir. (2017). Pengaruh sistem informasi akuntansi terhadap kualitas laporan keuangan pada SKPD Kabupaten Aceh Utara. Jurnal Akuntansi dan Pembangunan. 3(2), 46-57

Peraturan Pemerintah No 24 Tahun 2010. Standar Akuntansi Pemerintahan

Sugiyono. (2012). Metode penelitian bisnis. Alfabeta: Bandung.

Sugiyono. (2013). Metode penelitian bisnis. Alfabeta: Bandung

Susanto, Azhar. (2018). Sistem informasi akuntansi: struktur pengendalian-resikopengembangan, ed. Pertama, Cetakan Pertama, Lingga Jaya: Bandung.

Wijaya, Kusuma. (2018). Analisis kualitas keuangan bank daerah lamongan melalui sistem pengendalian internal (study pada Bank Daerah Lamongan). Jurnal Penelitian Ilmu Manajemen. III(3), 295-807. 
Lampiran

Hasil Uji validitas

\begin{tabular}{|c|c|c|c|c|}
\hline Variabel & $\begin{array}{c}\text { Item } \\
\text { Pertanyaan }\end{array}$ & rhitung & $\mathbf{r}_{\text {tabel }}$ & Keterangan \\
\hline \multirow{10}{*}{$\left(\mathrm{X}_{1}\right)$} & 1 & 0,395 & 0,304 & Valid \\
\hline & 2 & 0,376 & 0,304 & Valid \\
\hline & 3 & 0,498 & 0,304 & Valid \\
\hline & 4 & 0,815 & 0,304 & Valid \\
\hline & 5 & 0,720 & 0,304 & Valid \\
\hline & 6 & 0,632 & 0,304 & Valid \\
\hline & 7 & 0,636 & 0,304 & Valid \\
\hline & 8 & 0,491 & 0,304 & Valid \\
\hline & 9 & 0,445 & 0,304 & Valid \\
\hline & 10 & 0,638 & 0,304 & Valid \\
\hline \multirow{10}{*}{$\left(\mathrm{X}_{2}\right)$} & 1 & 0,311 & 0,304 & Valid \\
\hline & 2 & 0,334 & 0,304 & Valid \\
\hline & 3 & 0,553 & 0,304 & Valid \\
\hline & 4 & 0,652 & 0,304 & Valid \\
\hline & 5 & 0,682 & 0,304 & Valid \\
\hline & 6 & 0,708 & 0,304 & Valid \\
\hline & 7 & 0,572 & 0,304 & Valid \\
\hline & 8 & 0,612 & 0,304 & Valid \\
\hline & 9 & 0,636 & 0,304 & Valid \\
\hline & 10 & 0,491 & 0,304 & Valid \\
\hline \multirow{10}{*}{$(\mathrm{Y})$} & 1 & 0,876 & 0,304 & Valid \\
\hline & 2 & 0,869 & 0,304 & Valid \\
\hline & 3 & 0,819 & 0,304 & Valid \\
\hline & 4 & 0,769 & 0,304 & Valid \\
\hline & 5 & 0,692 & 0,304 & Valid \\
\hline & 6 & 0,759 & 0,304 & Valid \\
\hline & 7 & 0,861 & 0,304 & Valid \\
\hline & 8 & 0,829 & 0,304 & Valid \\
\hline & 9 & 0,780 & 0,304 & Valid \\
\hline & 10 & 0,745 & 0,304 & Valid \\
\hline
\end{tabular}

Sumber : Data diolah, 2020 